Research Article

\title{
Effects of intravenous midazolam during spinal anaesthesia for caesarian section
}

\author{
Bipul Deka ${ }^{1}$, Bharat Talukdar ${ }^{2}$, Amal Kumar Laha ${ }^{1}$, Susmita Borah ${ }^{1}$
}

\begin{abstract}
${ }^{1}$ Department of
Anaesthesiology, ${ }^{2}$ Department of Obstetrics and Gynaecology, Fakhruddin Ali Ahmed Medical College, Barpeta, Assam, India
\end{abstract}

Received: 17 February 2016 Accepted: 21 March 2016

\section{*Correspondence to: \\ Dr. Bipul Deka, \\ Email: drbipuldeka99 \\ @gmail.com}

Copyright: (C) the author(s), publisher and licensee Medip Academy. This is an openaccess article distributed under the terms of the Creative Commons Attribution NonCommercial License, which permits unrestricted noncommercial use, distribution, and reproduction in any medium, provided the original work is properly cited.

\begin{abstract}
Background: Spinal anaesthesia for caesarian section is associated with hypotension, bradycardia, and nausea and vomiting. The study was done to evaluate the safety and efficacy of sub hypnotic dose of midazolam in prevention of intraoperative complication of caesarian section under spinal anaesthesia.
\end{abstract}

Methods: In this study one group of women $(\mathrm{N}=250)$ received midazolam 0.02 $\mathrm{mg} / \mathrm{kg}$ bolus immediately after delivery of baby and $0.01 \mathrm{mg} / \mathrm{kg}$ half hourly. Equal number of women who received placebo was taken as control group. Intraoperative emetic episodes, scores of sedation and mephentermine consumption were recorded.

Results: Proportions of intraoperative nausea and vomiting were $12 \%$ and $51 \%$ in midazolam and control groups respectively $(\mathrm{p}<0.0001)$. To maintain the haemodynamic stability the requirement of mephentermine was significantly less in midazolam receiving women $(\mathrm{p}<0.0001)$. Twelve women of control group and no women of midazolam group required atropine. The number of patients that required tramadol $50 \mathrm{mg}$ or more for chest pain, shoulder pain and headache was significantly lesser in midazolam group than in control group $(\mathrm{p}<0.001)$. Oxygen supplementation was necessary for more number of women of midazolam group (14\%) than of control group (2.8\%).

Conclusions: Sub hypnotic doses of midazolam are safe and significantly reduce the incidence and severity of hypotension, bradycardia, nausea, vomiting and chest pain during caesarian section under spinal anaesthesia. Routine supplementation of oxygen may be necessary when midazolam is used.

Keywords: Midazolam, Caesarian section, Spinal anaesthesia

\section{INTRODUCTION}

Over the years central neuraxial block has become the choice of anaesthesia for caesarian section. It has its own set of complications, with hypotension being the commonest. Despite achieving adequate (T4) block, some women under spinal anaesthesia experience some degree of discomfort during caesarian section. Spinal anaesthesia with deep sedation is not a safe technique. ${ }^{1,2}$ This study was done to evaluate the efficacy of sub hypnotic dose of midazolam in reducing complications of spinal anaesthesia for caesarian section.

\section{METHODS}

This study was carried out in the operation theatre of obstetrics and gynaecology of a medical college, Fakhruddin Ali Ahmed Medical College, Barpeta, Assam, India. After institutional ethics committee approval written informed consent was taken from all patients who met the selection criteria. Patients were randomly allocated using a random number table into two groups. One group of women $(\mathrm{N}=250)$ received midazolam $0.02 \mathrm{mg} / \mathrm{kg}$ bolus immediately after delivery of baby and $0.01 \mathrm{mg} / \mathrm{kg}$ half hourly. Equal number of women that received placebo was taken as control group. The patients of American society of anesthesiologists 
(ASA) grade 1 and 2, undergoing elective caesarian section were recruited for the study. Patients with acidosis, diabetes mellitus, and gastro-intestinal disease, on antiemetic medication, obstetric complications such as antepartum haemorrhage, severe hypertension and disorder of coagulation profile were excluded from the study. Midazolam $0.03 \mathrm{mg}$ per $\mathrm{kg}$ body weight was taken in $5 \mathrm{ml}$ syringe and diluted with normal saline to make it $3 \mathrm{ml}$ solution. For placebo $3 \mathrm{ml}$ of normal saline was taken in a $5 \mathrm{ml}$ syringe. Solutions were prepared by a person not involved in the study. The anaesthetist who was blinded to the drug administered to patient injected 2 $\mathrm{ml}$ of solution immediately after delivery of baby and 1 $\mathrm{ml}$ of solution 30 minutes after the first dose.

All women received about $500 \mathrm{ml}$ of ringer lactate solution prior to performing the subarachnoid block. Hyperbaric bupivacaine $12 \mathrm{mg}$ with bupregesic $0.1 \mathrm{mg}$ were injected through 25 gauge spinal needle at the L3-4 or L4-5 interspaces. After spinal injection women were turned to supine position with $5^{0}$ head down tilt. The level of analgesia was assessed by pinprick. Surgery was allowed to commence when adequate level of anaesthesia is obtained (sensory level at T5 dermatome bilaterally). Patients were monitored with electrocardiogram (ECG), pulse oximetry and non-invasive blood pressure (NIBP). Non-invasive BP was monitored at 3 minutes interval. Oxygen was administered only if oxygen saturation fell below 95\%. Hypotention (decrease in systolic blood pressure of $20 \%$ or more from baseline values or absolute decrease to $100 \mathrm{~mm} \mathrm{Hg}$ ) was treated by increasing the rate of fluid administration, $15^{0}$ left lateral tilt and incremental doses of mephentermine. Oxytocin was administered at dose of 5 units of slow bolus following delivery of infant and infusion of 10 units in $500 \mathrm{ml}$ of fluid.

Intra-operatively, emetic episodes, consumption of mephentermine, requirement of atropine and any other drugs were recorded. Sedation was assessed using the Ramsey Sedation Scoring half hourly up to 1 hour after completion of surgery. ${ }^{3}$ The calculation of sample size was done on the basis of incidence of chest pain (14\%) and emetic episodes $(55 \%)$ of a pilot study on caesarian section under spinal anaesthesia. To detect a difference of $14 \%$ with level of significance of $95 \%$ and power of $80 \%$, the required sample size is 190 patients (two sided two tests).

\section{RESULTS}

There were no significant differences in demographic parameters between the two groups (Table 1). The incidences of nausea, vomiting and chest pain were significantly less in midazolam group than in control group. The incidence of shivering did not differ significantly between two groups (Table 2). Oxygen supplementation was necessary for more number of women of midazolam group (14\%) than of control group $(2.8 \%)$. The difference was found to be statistically significant (Fisher's exact test, P-value <0.0001). The sedation scores of women of both groups were found to vary from 1 to 2 before delivery of baby. All women had sedation score of 2 after delivery of baby.

Twelve women $(4.5 \%)$ of control group required atropine, ten of them for persistent low BP with normal heart rate (50-70 beat/min) after even injecting two incremental doses of mephentermine within 5 minutes (Table 3). Two women experienced discomfort with bradycardia $(\leq 45$ beat/min). No patient in midazolam group required atropine.

Table 1: Demographic parameters in the two groups.

\begin{tabular}{|lcll|}
\hline Variables & $\begin{array}{l}\text { Midazola } \\
\text { m group }\end{array}$ & $\begin{array}{l}\text { Control } \\
\text { group }\end{array}$ & $\begin{array}{l}\text { P } \\
\text { value }\end{array}$ \\
\hline Age & $24.8 \pm 4.776$ & $25.23 \pm 2.347$ & 0.1010 \\
\hline Height (Inch) & $62.3 \pm 1.321$ & $62.5 \pm 1.467$ & 0.0544 \\
\hline Weight (kg) & $58.43 \pm 9.40$ & $57.9 \pm 8.34$ & 0.2526 \\
\hline $\begin{array}{l}\text { Multiparas } \\
\text { (No. of women) }\end{array}$ & 85 & 90 & - \\
\hline $\begin{array}{l}\text { Duration of } \\
\text { operation (min) }\end{array}$ & $43.55 \pm 7.45$ & $43.25 \pm 6.56$ & 0.6241 \\
\hline Apgar score 1 min & $8-9$ & $8-9$ & - \\
\hline Apgar score 5 min & $9-10$ & $9-10$ & - \\
\hline
\end{tabular}

Table 2: Incidence of complication.

\begin{tabular}{|llll|}
\hline & Midazolam N=250 & Control N=250 & P* (Fisher's Exact Test) \\
\hline Nausea and vomiting -Before delivery & $2 \%(5 / 250)$ & $3 \%(7 / 250)$ & 0.7717 \\
\hline After delivery & $12 \%(30 / 250)$ & $50 \%(125 / 250)$ & $<0.0001$ \\
\hline Total & $12 \%(30 / 250)$ & $51 \%(127 / 250)$ & $<0.0001$ \\
\hline Vomiting & & & \\
\hline Before delivery & - & - & - \\
\hline After delivery & $2 \%(5 / 250)$ & $6 \%(15 / 250)$ & 0.0374 \\
\hline Total & $2 \%(5 / 250)$ & $6 \%(15 / 250)$ & 0.0374 \\
\hline Shivering & 22 & 24 & 0.8772 \\
\hline Chest pain/discomfort & $3((1.2 \%)$ & $15(6 \%)$ & 0.0065 \\
\hline Shoulder pain & 0 & 3 & 0.2485 \\
\hline
\end{tabular}


Table 3: Medicines administered.

\begin{tabular}{|lccl|}
\hline \multicolumn{1}{|c|}{$\begin{array}{c}\text { Midazolam } \\
\text { group }\end{array}$} & $\begin{array}{l}\text { Control } \\
\text { group }\end{array}$ & $\begin{array}{l}\text { P value } \\
\text { (Fisher's } \\
\text { exact test) }\end{array}$ \\
\hline $\begin{array}{l}\text { Tramadol 50 mg or } \\
\text { more (No. of } \\
\text { patients) }\end{array}$ & 3 & 18 & $<0.001$ \\
\hline $\begin{array}{l}\text { Ergometrine } \\
\text { (No. of patients) }\end{array}$ & 5 & 6 & $\mathrm{NS}$ \\
\hline $\begin{array}{l}\text { Corboprost (No. of } \\
\text { patients) }\end{array}$ & 7 & 8 & $\mathrm{NS}$ \\
\hline $\begin{array}{l}\text { Atropine (No. of } \\
\text { patients) }\end{array}$ & 0 & 12 & 0.0004 \\
\hline $\begin{array}{l}\text { Mephentermine } \\
\text { (mg) }\end{array}$ & $6.833 \pm 5.764$ & $12 \pm 8.388$ & $<0.0001$ \\
\hline $\begin{array}{l}\mathrm{O}_{2} \text { Supplement } \\
\text { (No. of patients) }\end{array}$ & $35(14 \%)$ & $7(2.8 \%)$ & $<0.0001$ \\
\hline
\end{tabular}

\section{DISCUSSION}

We found that women of midazolam group experienced significantly fewer episodes of nausea and vomiting (12\%), compared to control group (51\%). The incidence of nausea in control group is similar to incidence reported by D. Ure et al. ${ }^{4}$ The lower rate of nausea in midazolam group is similar to finding of O. Tarhan et al. ${ }^{5}$ The mechanism of anti- emetic effect of midazolam is not well known. Midazolam acts on chemoreceptor trigger zone to reduce synthesis, release and postsynaptic effect of dopamine. The anxiolytic effect of midazolam may also contribute to antiemesis.

The severity of hypotensive episodes in the midazolam group was less than in the control group, as demonstrated by a reduction in mephentermine dose required to treat hypotension $(p<0.0001)$. Twelve women of control group and no women of midazolam group required atropine. Atropine was used to treat bradycardia $(\leq 50 / \mathrm{min})$ or hypotension with relative bradycardia $(50-70 / \mathrm{min})$ not adequately responding to mephentermine alone. Reflex cardiovascular depression that is known as vasovagal syncope, the Bezold Jarish reflex or neurocardiogenic syncope occurs during caesarian section under spinal anaesthesia. ${ }^{6,7}$ It is demonstrated that low dose of midazolam is effective in reducing vasovagal responses. Sousan et al reported that midazolam, but not propofol in sub hypnotic dose, was effective in maintaining haemodynamic stability. ${ }^{8}$

Low dose of tramadol $(25 \mathrm{mg})$ was administered for treating women who developed shivering. This low dose of tramadol has no significant effect on nausea and vomiting. ${ }^{9}$ The number of women that required tramadol $50 \mathrm{mg}$ or more for chest pain and shoulder pain was significantly lesser in midazolam group than in control group $(\mathrm{p}<0.001)$. It is known that IV opiods, ergomentrine and carboprost cause increased incidence of emesis during caesarian section under spinal anaesthesia. Midazolam may not be effective as antiemetic if patients receive those drugs. In our study as the women treated with ergometrine or carboprost and tramadol $50 \mathrm{mg}$ or more are small in number, we cannot confirm the observation.

The increased incidence of $\mathrm{O}_{2}$ desaturation with sub hypnotic dose couldn't be explained. There has been no study of the effects of low doses of midazolam $(0.02 \mathrm{mg}$ $\mathrm{kg}-1)$ on respiration. It was reported that midazolam causes respiratory depression with doses of 0.15 to $0.2 \mathrm{mg}$ $\mathrm{kg}-1 .^{10}$ Routine supplementation of oxygen isn't necessary during spinal anaesthesia for elective caesarian section. ${ }^{11}$ As we found high incidence of oxygen saturation dropping below $95 \%$ in the midazolam group, routine oxygen supplementation may be necessary when midazolam is used. ${ }^{12}$

It was found that midazolam significantly reduces incidence of chest pain or chest discomfort $(1.2 \%$ in midazolam group versus $6 \%$ in control group). Myocardial ischaemia from oxytocin and hypotension, and air embolism may be the causes of chest pain in spite of adequate level of block. ${ }^{13,14}$ The cause of shoulder pain may be amniotic fluid or blood under the diaphragm. Tilting the operation table to head up position may be helpful.

Table 4: Appendix; Ramsey sedation scoring.

\begin{tabular}{|lc|}
\hline Observations & Score \\
\hline Anxious, agitated, restless & 1 \\
\hline Awake, cooperative, oriented, tranquil & 2 \\
\hline Semi asleep but responds to command & 3 \\
\hline Asleep but responds to loud auditory stimulus & 4 \\
\hline $\begin{array}{l}\text { Asleep with decrease response to loud auditory } \\
\text { stimulus }\end{array}$ & 5 \\
\hline No response & 6 \\
\hline
\end{tabular}

\section{CONCLUSION}

Sub hypnotic doses of midazolam are safe and can significantly reduce the incidence and severity of hypotension, bradycardia, nausea, and vomiting and chest pain during caesarian section under spinal anaesthesia. Routine use of supplementary oxygen may be necessary when midazolam is used.

\section{Funding: No funding sources}

Conflict of interest: None declared

Ethical approval: The study was approved by the Institutional Ethics Committee

\section{REFERENCES}

1. Caplan RA, Ward RJ, Rosner K, Cheney FW. Unexpected cardiac arrest during spinal anesthesia: a closed claims analysis of predisposing factors. Anesthesiology. 1998;68:5-11. 
2. GeffinB, Shapio L. Sinus bradycardia and asystole during spinal and epidural anesthesia: a report of 13 cases. J clin Anesth. 1998;10:278-85.

3. Ramsay M, Savege TM, Simpson BRJ, Goodwin R. Controlled sedation with alpaxalone-alphadalone. British Medical Journal. 1974;2:656-9.

4. Ure D, James KS, McNeill, Booth JV. Glycopyrrolate reduces nausea during spinal anaesthesia for caesarian section without affecting neonatal outcome. British journal of anaesthesia. 1999;82:277-9.

5. Tarhan O, Canbay S, Celebi N, Vzun S, Sahin A, Caskun F, et al. Subhypnotic doses of midazolam prevent nausea and vomiting during spinal anesthesia for cesarean section. Minerva Anestesiol. 2007;73:629-33.

6. Pei-Shan $\mathrm{T}$, Chih-Ping $\mathrm{C}$, Ming-Song $\mathrm{T}$. Perioperative syncope with focus on obstetric anesthesia. Taiwanese J Obstet Gynecol 2006;45:208-14.

7. Kinsella SM, Tucky JP. Perioperative bradycardia and asystole: relationship to vasovagal syncope and the Bezold-Jarisch reflex. British Journal of Anaesthesia. 2001;86:859-68.

8. Rasooli S, Moslemi F, Khaki A. Effect of sub hypnotic doses of propofol and midazolam for nausea and vomiting during spinal anaesthesia for caesarian section. Anesthesiology and Pain medicine. 2014;4:19384.

9. Chan AHM, Ng Jacobus KF, Tong EWN, Jan GKS. Control of shivering under regional anesthesia in obstetric patients with tramadol. Can J Anesth. 1999;46:253-8.

10. Bell GD, Reeve PA, Moshiri M, Morden A, Coady T, Stapleton PJ, et al. Intravenous midazolam: a study of the degree of oxygen desaturation occuring during upper gastrointestinal endoscopy. Br J Clin Pharmac. 1987;23:703-8.

11. Backe SK, Lyons G. Oxygen and elective Caerean section. Br J Anaesth. 2002;88:4-5.

12. Di Florio T. Midazolam for PONV. What's new? Anaesthesia. 2002;57(9):941.

13. Svanstrom MC, Biber B, Johansson G, Naslund U, Balfors EM. Signs of myocardial ischaemia after injection of oxytocin: a randomized double blind comparison of oxytocin and methyle ergometrine during caesarian section. British Journal of Anaesthesia. 2008;100:683-9.

14. Karuparthy VR, Downing JW, Husain FJ, Knape KG, Blanchard J, Solomon D, et al. Incidence of venous air embolism is unchanged by use of a 5 to $10^{\circ}$ headup tilt. Anesth Analg. 1989;69:620-3.

Cite this article as: Deka B, Talukdar B, Laha AK, Borah S. Effects of intravenous midazolam during spinal anaesthesia for caesarian section. Int J Basic Clin Pharmacol 2016;5:754-7. 